\title{
Erratum to: Characterizing the Relative Contributions of Large Vessels to Total Ocean Noise Fields: A Case Study Using the Gerry E. Studds Stellwagen Bank National Marine Sanctuary
}

\author{
Leila Hatch • Christopher Clark • Richard Merrick • \\ Sofie Van Parijs · Dimitri Ponirakis · Kurt Schwehr • \\ Michael Thompson · David Wiley
}

Published online: 3 October 2009

(C) Springer Science+Business Media, LLC 2009 Erratum to: Environmental Management (2008) 42:735-752
DOI 10.1007/s00267-008-9169-4

A revised version of Table 4 is presented to correct conversion errors in the originally published table. In the corrected table, coarse estimates of the relative contributions of different sampled vessel types to the lowfrequency $(71-141 \mathrm{~Hz})$ band with the sampled region in 2006 were derived by first converting average source levels estimates (total power in the $70 \mathrm{~Hz}$ band) for vessels of each type from decibels to watts. Average power per vessel type (watts) was then multiplied by the total number of hours spent by vessels of each type in the sampling region in 2006 to get an estimate of the total power generated by each type over the course of the year (watt hours/year).

The online version of the original article can be found under doi:10.1007/s00267-008-9169-4.

L. Hatch $(\varangle) \cdot$ M. Thompson · D. Wiley

Gerry E. Studds Stellwagen Bank National Marine Sanctuary,

U.S. National Oceanic and Atmospheric Administration, 175

Edward Foster Road, Scituate, MA 02066, USA

e-mail: leila.hatch@noaa.gov

C. Clark $\cdot$ D. Ponirakis

Bioacoustics Research Program, Cornell University Laboratory of Ornithology, 159 Sapsucker Woods Road, Ithaca, NY 14850,

USA

R. Merrick · S. Van Parijs

Northeast Fisheries Science Center, U.S. National Oceanic and Atmospheric Administration, 166 Water Street, Woods Hole, MA 02543, USA

K. Schwehr

Center for Coastal and Ocean Mapping Joint Hydrographic

Center, University of New Hampshire, 24 Colovos Road,

Durham, NH 03824, USA
These estimates were then multiplied by the fractions of the year that each vessel type was present in the sampling region to provide estimates of average power (watts) generated by each vessel type per hour in 2006 within greater sanctuary waters. These values were then scaled relative to the lowest contributing vessel type (research vessels).

These corrections do not alter the results discussed in the paper, as the hierarchy of estimated relative contributions among vessel types remains unchanged. However, the noise contribution of tankers is now estimated to exceed the contributions of all other vessel types by an even greater margin than originally discussed. 
Table 4 Relative noise contributions of different vessel types to the sampling region's total ocean noise budget, based on average source level (SL) estimates, and total time spent in the sampling region

\begin{tabular}{|c|c|c|c|c|c|c|c|}
\hline Vessel type & $N$ & $\begin{array}{l}\text { Average } \\
\text { power } \pm \mathrm{SE} \\
(\mathrm{dB})\end{array}$ & $\begin{array}{l}\text { Average } \\
\text { power }(\mathrm{W})\end{array}$ & $\begin{array}{l}\text { Total time } \\
\text { w/in SBNMS } \\
\text { (hours/year) }\end{array}$ & $\begin{array}{l}\text { Total power } \\
\text { w/in SBNMS } \\
\text { (Whours/year) }\end{array}$ & $\begin{array}{l}\text { Average } \\
\text { power w/in } \\
\text { SBNMS (W) }\end{array}$ & $\begin{array}{l}\text { Relative } \\
\text { power w/in } \\
\text { SBNMS (W) }\end{array}$ \\
\hline Oil/chemical tanker & 4 & $182 \pm 2$ & 12.9 & 1702 & 21,925 & 4,260 & 460 \\
\hline LNG tanker & 1 & 182 & 12.9 & 1065 & 13,716 & 1,667 & 180 \\
\hline Cargo/Container & 3 & $179 \pm 2$ & 6.5 & 1481 & 9,563 & 1,617 & 175 \\
\hline Tug & 3 & $172 \pm 3$ & 1.3 & 2956 & 3,808 & 1,285 & 139 \\
\hline Cruise ship & 2 & $181 \pm 3$ & 10.2 & 394 & 4,035 & 182 & 20 \\
\hline Private yacht & 1 & 162 & 0.1 & 2343 & 302 & 81 & 9 \\
\hline Research & 2 & $160 \pm 2$ & 0.1 & 999 & 81 & 9 & 1 \\
\hline
\end{tabular}

within (w/in) 2006 and normalized to the vessel type with the lowest decibel contribution to facilitate comparison 